значения. Текст от XIII в. представляет контексты, в которых усиливается значение личных местоимений в истории русского языка. В древнерусском языке в качестве связки в составном именном сказуемом может использоваться форма бысть, а формы типа еси в составе перфекта, наоборот, теряют свою значимость и превращаются в модально-временной показатель.

В Заключении [SOKOLOVA 2017, 79-83] подытоживаются результаты проведенных автором исследований. Следуют резюме на чешском (Resumé [SOKOLOVA $2017,85-87$ ]) и на английском языке (Summary [SOKOLOVA 2017, 89-91], далее список Использованной литературы [SOKOLOVA 2017, 95-100]. В Приложении [SOKOLOVA 2017, 101-172] представлен мелким курсивом напечатанный обозор анализированных текстов и, наконец, Предметный указатель [SOKOLOVA $2017,175]$ - в нем приводятся употребляемые автором термины, связанные с темой работы; у каждого термина указаны страницы, где данный термин употребляется.

Рецензируемая монография представляет собой удачный труд, который затрагивает не только избранную тему по историческому развитию русского языка, но входит и в более широкие рамки славистического контекста, отчасти даже индоевропейского.

Алеш Бранднер

\title{
Библиография:
}

SOKOLOVA, A. (2017): Slavjanskije preterity s istoričeskoj točki zrenija: $k$ istorii form perfekta $v$ russkom jazyke (na materiale služebnych minej na maj XI-XIII vv.). Brno.

https://doi.org/10.5817/NR2019-1-6

\section{Našli nový domov a zanechali stopu (K nové knize o ruské meziválečné emigraci)}

КОПРШИВОВА, А.: Найти приют, оставить след... К столетию Чехословацкой республики. Praha: Ruská tradice, 2018. ISBN 978-80-906815-2-1.

V aktuálním společenském a mediálním diskursu bychom jen těžko hledali dvě diskutovanější látky, než je otázka migrace a rusofobního narativu. Obě tato témata jsou však presentována povícero bez znalosti historických a kulturních souvislostí 
a často bez racionálního základu. Především v tomto kontextu je třeba vnímat novu monografii Anastazie Kopřivové Найти приют, оставить след..., kterou u př́ležitosti stoletého jubilea novodobé české státnosti vydalo nakladatelství Ruská tradice.

Námětu ruské emigrace se u nás věnovala a věnuje řada badatelů. Vyšlo zdánlivě mnoho monografií, sborníků studií a odborných článků, memoárů, či speciálních edic. ${ }^{1}$ Avšak ucelený a stř́zlivě podaný obraz bezesporu neopakovatelného a interesantního fenoménu ruské meziválečné emigrace spojené s tzv. Ruskou pomocnou akcí stále čeká na zpracování. Většina dosavadních monografií je pojata namnoze historizujícím a výčtově bohatě faktografickým stylem. Jen okrajově jsou zmiňovány a analyzovány širší souvislosti politické, národnostní, sociální, kulturní, psychologické či konfesní. Obraz ruské emigrace tak stále zůstává neúplný a plochý.

Jednu z mezer $\mathrm{v}$ obrazu ruské emigrace, převážně ruské inteligence, se podařilo zaplnit Anastázii Kopřivové ve zmiňované knize. Autorce se povedlo zachytit lidský rozměr osudů ruských exulantů bez zbytečného patosu a historizujících výčtů. Na pozadí dobového dění zobrazuje především konkrétní osudy a př́běhy lidí, kteří ztratili svůj domov, byli k životu v Čechách hnáni úsilím o záchranu holého bytí, motivováni úsilím být užitečný, mít př́ležitost se uplatnit a realizovat pokud možno plnohodnotný a smysluplný život v nové zemi.

Nejde však o beletrii, ale o knihu, která se pokouší v časové lince nastínit z pohledu obyčejného života konkrétních lidí vznik, průběh a částečně i zánik více jak třicetitisícové komunity ruských vyhnanců. Nejen proto, že A. Kopřivová je jednou z největších světových znalkyň dané matérie, ale i proto, že sama je potomkem první vlny ruské emigrace, dokáže velmi citlivě popsat, co vše obnášela možnost žít a uživit se, pracovat, získávat vzdělání, realizovat své tvưrčí a profesní schopnosti a dovednosti, najít bydlení a nový domov. Umí proto velmi jemně rozlišit, co nese prostá formální pomoc státu, která může zajistit jen pro první okamžiky vlastní přežití, a co obnáší zapojit se do společnosti a být ji k užitku.

Kniha začíná logicky u příběhů československých legionářů, kteří tvořili jeden z piliřrou rusko-českého poznávání. Byly to nejen praktické znalosti ruského prostředí nabyté vojenskou anabází, ale u velké řady z nich i ruské manželky, které byly posléze nejméně pro další dvě tři generace potomků nositelkami ruských zvyků, bájesloví i mentality. Byli to však třeba i dva živí medvídci, které prezidentu Masarykovi přivezli z Ruska bratři legionáři a kteří $\mathrm{v}$ medvědinci Pražského hradu patřili k neopominutelným pražským atrakcím připomínající Rusko.

Linka osudů ruských emigrantů pokračuje osobními vřelými vztahy T. G. Masaryka k ruské emigraci. Masaryk byl nejen iniciátorem Ruské pomocné akce, donátorem

1 Za všechny jmenujme z posledních prací např. [GAGEN 2017; BABKA, ZOLOTEREV 2012; ANIKINA 2008; POSPÍŠIL 2015; SLÁDEK 2010]. 
i sponzorem mnoha členů ruské emigrantské komunity, ale byl i její nejmenovanou intelektuální, lidskou a politickou autoritou. Mimo jiné i proto, že byl skvělým znalcem ruské kultury a vědy. Podle oficiálních dokladů tvořili ve dvacátých letech ruští intelektuálové až dvacet procent návštěv, s nimiž se Masaryk stýkal. Také na sklonku života ho až do posledních okamžiků doprovázela ruská pečovatelka, jež mu třeba předčítala $v$ originále $z$ ruské literatury, kterou miloval a rozuměl ji. I z těchto příběhů je možné vyčíst to, co zatím literatura o ruské emigraci pomíjela. Pro Masaryka byla jedním z možných mezičlánků budoucího evropského sjednocení, o němž snil, reprezentovala v sobě hluboce kulturní, liberální a demokratické hodnoty, které sovětské Rusko tehdy brutálně pošlapalo.

$\mathrm{V}$ druhé části knihy se A. Kopřivová věnuje často strhujícím a dosud nepopsaným osudům vybraných velkých osobností ruské emigrace, které z původní vlasti vyhnal bolševický převrat, vědcům, filozofům, lékařům, právníkům, inženýrům, spisovatelům, nebo umělcům, zkrátka těm, díky nimž se Praze přezdívalo ruské Athény či ruský Oxford. Patřili mezi ně třeba knížata Pavel a Petr Dolgorukovi, potomci carského roku Rurikovců. Byl to profesor ČVUT inženýr Aleksej Lomšakov, jenž organizoval podporu studií pro stovky nemajetných dětí ruských utečenců. Byl to i Aleksej Surin, hrdina obou světových válek a konstruktér nejúspěšnějšího československého tanku LT Vz. 38. Byla to i „bába“ ruské revoluce Kateřina Breško-Breškovská, které se rudý teror odvděčil tak, že sotva stačila utéct z Ruska s pomocí českých legionářù. Podobné byly i osudy Aleksandry Žegulinové, desítek příslušnic ruského Červeného křǐže, ale také „bílých“ vojáků, námořníků, kozáků a dalších, jejichž osudy čekají na podrobnější zpracování.

Třetí část knihy je věnována místům setkávání ruské emigrace a místům jejího poznávání českého prostředí. V tomto „staronovém“ paradigmatu autorka přibližuje místa, jako byl Ruský dům (dnešní hotel Palace v Praze), ruské dětské jesle a mateřské školy, ruská gymnázia, vysoké školy, studentské koleje a „profesorské domy“, muzea, knihovny, redakce ruských periodik, svobodárny, vyvařovny a restaurace i další hlavně pražské lokality, které si pro svoji podivuhodnou magičnost oblíbili třeba ruští umělci v čele s Marinou Cvetajevovou.

Ruským zvykům a rodinným tradicím je věnována další část publikace. Jde o látku dosud systematicky nezpracovanou a tak velmi př́nosnou jak pro jazykovědce, tak i pro sociology, etnografy nebo folkloristy. $V$ této části publikace jsou popisovány ruskou emigrací ctěné a zároveň do nového prostředí transformované významné ruské svátky a obyčeje, ale i jídlo, oblečení, způsoby chování a etiketa... zkrátka vše, čemu se ruským všeobjímajícím slovem říká „быт“, mnohé z toho, co se po četná desetiletí udržuje v řadě rodin potomků ruské emigrace. Patří sem tzv. Den Tatjány, ruské Vánoce, Velikonoce, plesová sezóna, tance, písně, pohádky, báje a pověsti, pověry, lidová řemesla, kroje, specifická jídla a nápoje, a to nejen ta, která dnes v Čechách 
zná každý, jako třeba boršč, ale i ta, jejichž příprava je dodnes střežena potomky jako cenné rodinné stř́bro.

Poslední stránky jsou pamětí na období nejsmutnější pro první vlnu ruské emigrace, roky válečné a zejména pak doba po květnu 1945, kdy stovky emigrantů byly odvlečeny sovětskými tajnými a policejními službami do gulagů Sovětského svazu bez soudu, bez jakýchkoliv důvodů. Velká část z nich zmizela beze stopy, malá část se po mnoha letech vrátila. $O$ jejich osudech však dále vyprávějí pomníčky na ruském pravoslavném hřbitově na pražských Olšanech. I dřevo a kameny dokáží předávat poselství o naší paměti a o osudech těch, kteří se přes nepř́zeň osudu nikdy nevzdali a dokázali v cizí zemi najít nový domov a zanechat svým životem a dílem $\mathrm{v}$ nové vlasti nesmazatelnou stopu.

Celkově vyznívá poselství knihy Anastazie Kopřivové jako nosný příspěvek do studia $\mathrm{v}$ naší novodobé historii výjimečného úkazu masové migrace, která byla iniciována mj. pragmatismem tehdejší československé vlády. Ukazuje též na proces využití potenciálu ruské intelektuální a kulturní obce i jeho synergie dopadající na společenský, vědecký, kulturní i běžný život v naší zemi.

Michail Odarčenko

\section{Bibliografie:}

ANIKINA, T. a kol. (2008): Dom v izgnanii, Očerki o russkoj èmigracii v Čechoslovakii 1918-1945. Praha.

BABKA, L., ZOLOTEREV, I. (eds) (2012): Russkaja akcija $v$ Čechoslovakii, istorija, značenije, nasledije. K go-letiju načala Russkoj akcii pomošči. Praha.

GAGEN, S. Ja. a kol. (2017): Zkušenost exilu, Osudy exulantů z území bývalého Ruského impéria v meziválečném Československu. Praha.

KOPRŠIVOVA, A. (2018): Najti prijut, ostavit' sled... K stoletiju Čechoslovackoj respubliki. Praha.

POSPÍŠIL, I. (2015): Znovu $k$ naší pomoci ruské meziválečné emigraci. Proudy, 2015, č. 1. <http://www.phil.muni.cz/journal/proudy/revue/eseje_fejetony/2015/1/ pospisil_polemika_k_ruske_emigraci.php>. [online]. [cit. 10. 2. 2019].

SLÁDEK, K. (2010): Ruská diaspora v České republice. Sociální, politická a regionální variabilita ruských emigrantů. Červený Kostelec. 